\title{
"CARNE SEM OSSO E FARINHA SEM CAROÇO": O MOTIM DE 1858 CONTRA A CARESTIA NA BAHIA
}

\author{
João José Reis* \\ e \\ Márcia Gabriela D. de Aguiar** \\ Departamento de História - UFBa
}

\begin{abstract}
RESUMO: Estudo de um motim contra a carestia na Bahia, em 1858. Os autores narram os eventos, discutem o perfil dos participantes e analisam o movimento enquanto defesa de uma "economia moral", mas enfatizando também sua dimensão política.
\end{abstract}

ABSTRACT: This article is a study of a food riot in Bahia in 1858. The authors describe the events, discuss the profile of the protestors, analyze the movement as a defense of the "moral economy" and emphasize its political magnitude.

PALAVRAS-CHAVE: carestia, rebeldia, economia moral, Bahia, século XIX.

KEYWORDS: food riot, rebellion, "moral economy", Bahia, nineteenth century.

Ao longo do século XIX, a Bahia sofreu graves crises de abastecimento que ocasionaram a carestia dos gêneros de primeira necessidade, como a farinha de mandioca e a carne verde. Em algumas ocasiōes as crises foram acompanhadas de tensōes populares, que ameaçaram uma estabilidade precária porque

* Agradecemos ao CNPq pelo apoio à pesquisa que levou à elaboração deste artigo, Jos̄o Reis com bolsa de produtividade, Márcia Gabriela Aguiar com bolsa PIBIC. Este artigo é para E. P. Thompson, in memorium. freqüentemente sacudida por outros tipos de revolta, fossem movimentos federalistas, levantes militares ou rebeliões escravas. Às vezes, como nos movimentos denominados mata-marotos entre 1824 e 1831 - este último ano particularmente lusófobo-, manifestantes atacariam com violência comerciantes portuguescs (os "marotos"), suas casas e lojas, em açōes que combinavam nativismo e protesto contra a carestia.'

1. Sobre esses movimentos, ver por exemplo Morton (1974): Reis (1976); Souza (1987); Aras (1995). 
O motim da "carne sem osso e farinha sem caroço", ocorrido em 1858, não foi então um caso isolado de movimento popular na Bahia no século XIX. Foi, no entanto, aquele que melhor caracterizou um food riot, expressão consagrada na historiografia internacional para definir de forma sintética os protestos mais ou menos violentos contra a carestia e a escassez de alimentos. ${ }^{2}$

$\mathrm{Na}$ literatura histórica internacional prevaleceu durante muito tempo a visão de que esses movimentos eram causados tão somente por substanciais, $e$ com freqüência repentinas, altas nos preços dos alimentos. Segundo esta visão, os movimentos seriam explicados a partir da barriga dos indivíduos neles envolvidos. Mais recentemente, sobretudo a partir da década de 1970, historiadores dedicados ao assunto vêm demolindo esta perspectiva. Sem desconsiderarem o aumento de preços como um fenômeno importante na cadeia explicativa, eles demonstraram que não se pode estabelecer uma relação de causalidade imediata entre fome e revolta. Muitas situaçōes de escassez alimentar e alta de preços aconteceram e acontecem na história sem que o povo se rebele, ou populaçōes submetidas às mesmas pressões de escassez alimentar podem reagir diferentemente, umas se rebelando, outras não. Alguns episódios de food riots tiveram lugar em épocas de relativa abundância alimentar, associados a um temor dos consumidores quanto à permanência da bonança. Finalmente, e associado a este último ponto, tais motins

2. Alêm de food riot (literalmente motim de comida), outras expressōes têm sido menos usadas como meal riot, hunger riot. subsistence riot. Em francês a expressão taxation populaire se refere à imposiçāo do "preço justo" dos alimentos, uma das principais formas desse tipo de movimento. Outros termos: émeute de subsistances, revolte frumentaire e guerre des farines. podiam acontecer em momentos quando, em meio a crises políticas, se verificava uma crise de abastecimento geralmente associada a fatores climáticos ou mudanças bruscas de práticas e leis comerciais. ${ }^{3}$

Talvez a mais influente interpretação sobre esse tipo de protesto tenha sido introduzida por E. P. Thompson. Num estudo que já se tornou clássico (THOMPSON, 1971), ele combateu duramente os historiadores que viam o food riot como expressāo imediata da fome ou, dito de outra forma, meramente como a resposta do povo a curvas ascendentes nos preços dos alimentos. Viu nisso excesso de fidelidade dos historiadores econômicos a sua matéria. Nāo que, por ocasião da maioria desses movimentos, os preços estivessem baixos e a escassez inexistisse, mas tais circunstâncias para ele deveriam marcar o início da discussão e nāo seu epílogo. Adotando uma perspectiva mais antropológica, Thompson argumentaria que se deveria entender tais levantes relacionando-os aos valores coletivos a respeito do preço justo e da responsabilidade dos governantes em manter abastecido o mercado de alimentos. O historiador chamou a cstc sistcma de valores de "cconomia moral da multidāo" ("moral economy of the crowd"). Num trabatho mais recente ele ampliou sua definiçāo dos motins fundamentados na economia moral:

"confrontaçōes no âmbito do mercado em torno do acesso [...] a 'necessidades' - comida bísica. O que emprestava uma carga 'moral' específica ao protesto nåo era apenas a existência de um conjunto identificável de crenças, usos e formas associa-

3. A bibliografia sobre o assunto é enorme e o debate pode ser acompanhado nas páginas da revista inglesa Past \& Present das últimas três décadas. Trabalho pioneiro de revisāo foi de Rudé (1964. passim). Ver mais Thompson (1971; 1991); Stevenson (1979, cap. 5); Louise Tilly (1971); Williams (1976). 
dos a comercializaçāo de comida em tempo de escassez [...], mas as emoçōes profundas agitadas pela escassez, as queixas que a Inultidzo fazia junto às autoridades em tais crises e a indignação provocada pela busca de lucro em situaçôes emergenciais que ameaçavam vidos. Tudo isso combinadoé o que entendo por economia moral." (THOMPSON, 199i, pp. 337-8).

Thompson chamou os rebeldes de "multidão" (em inglês crowd), acompanhando George Rudé e outros historiadores revisionistas, com o intuido de evitar o termo mais pejorativo "turba" (mob), freqüentemente usado com conotações de irracionalidade, de massa humana mcio amorfa, desorientada, desorganizada, destrutiva, como a foule de Gustave Le Bon. ${ }^{4}$ A turba dos food riots surge nessa perspectiva como dona de uma psicologia coletiva mais relacionada com a barriga do que com a cabeça, sugerindo que os rebeldes se comportariam de forma espontânea e suas açōes se esgotariam no próprio ato de protesto. A esse tipo de análise Thompson (1971, p. 70) se referiu como "visão espasmódica da história popular".

Já a "multidāo" de Thompson se orientava e se organizava a partir de valores previamente forma-

4. O termo "cronvd" foi também criticado por Roben Holton (1978) por razðes seınelhantes às que levaram Thompson a adotálo. Elc critica sobretudo um certo reducionismo econômico $\mathrm{c}$ um evolucionismo presentes na obra de Rudé (1964). Evolucionismo também encontrado $\mathrm{cm}$ Hobsbawn (1959), que utiliza expressões como "primitive rebels". "pre-politicar" e mesıno "mob", nâo obstante seu engajamento politico. Ver os comentários críticos a Hobsbawn (1979) de Boris Fausto, Maria Isaura P. de Queiros, Octávio Vełho e Verena Stolcke. Quanto a Le Bon (1960). autor do clássico Psychologie des foules publicado originalmen. te cm 1895, vejam o que cle escreveu: "As massas só têm poder para destruir" (p. 18); ou ainda, no participante da multidjo hs "um desaparecimento da atividade da mente" (p.31); e mesmo dos, numa sociedade ainda predominantemente paternalista (ele escrevia sobre a Inglaterra do século XVIII) e que esses valores, nesse ambiente, conformavam a lógica da ação coletiva. Nesse sentido não havia nada de espontâneo nos food riots, o que se confirma pelo caráter ritualizado com que freqüentemente os amotinados representavam seu papel. Pode-se mesmo dizer que havia muito de político. Os consumidores, em revoltas às vezes cheias de protocolos e disciplina, buscavam colocar as coisas no devido lugar, chamando os governantes a seus deveres, e lembrando-lhes que tinham direitos, tradicionalmente estabelecidos, a comida barata e se possível boa, assim como penalizavam comerciantes $\mathrm{e}$ atravessadores inescrupulosos cujo comportamento mercantil apontava para a instauração de um mercado apenas regulado pela lógica econômica capitalista, em detrimento de compromissos morais. E este tipo de mercado nem sempre era "livre", no sentido da concorrência, mas freqüentemente dominado por monopolistas. ${ }^{3}$

Há uma distância muito grande separando a Inglaterra setecentista, com seu emergente capitalismo industrial, e a Bahia oitocentista, com sua eco- un homem culto, quando membro da multidão, "ele é um bárbaro - isto é, umna criatura agindo pelo instinto" (p. 32).

5. "The Moral Economy" foi republicado na integra em Thompson (1991, cap. iv). Neste mesmo volume, que enfecha vários artigos antes publicados, o autor acrescenta um longo ensaio ("The Mornl Economy Reviewed". pp. 259-371) retomando a tejnática da "economia moral" e respondendo a seus críticos. Mantendo o fundamental, ver interessante crítica de aspectos da concepçāo thompsiana em Bohstedt (1992). No ensaio acima mencionado. Thompson responde antecipadamente a várias dessas criticas, além de trucidar Williams (1984), um crítico mais fraco cujas idéias convergem com as de Bohstedı em alguns pontos importantes. 
nomia agrário-exportadora escravista. No entanto, sem precisar segui-los à risca, é possível pensar essa Bahia a partir das sugestões de Thompson e outros historiadores dos food riots e assim tentar lançar uma nova luz sobre o movimento de 1858. Como veremos, esteve então em jogo - embora não exclusivamente - a disputa entre uma economia moral do paternalismo e uma economia política do laissez-faire, disputa semelhante à que tivera lugar na Inglaterra do século anterior. Afinal, a "economia de mercado" capitalista se internacionalizaria - sendo este aliás um de seus elementos formadores - criando, onde penetrava, tensões e reaçōes parecidas, embora com dimensōes e intensidade variáveis. O food riot, uma forma de protesto habitual na Europa do século XVIII e, com menor intensidade, no século $\mathrm{XIX}$, aconteceu em várias regiōes integradas à economia mundial, e continua a acontecer de vez em quando principalmente nos países do chamado Terceiro Mundo. Obviamente, tanto as crises de carestia e abastecimento geradas por este processo como as reaçōes a elas irāo ganhar características do contexto local. ${ }^{6}$ A Bahia de 1858 foi um desses contextos.

\section{O motim}

A história dos acontecimentos é meio confusa. Foi o que o Jornal da Bahia (1.03.1858) avisou a seus leitores na frase que abria o noticiário a respeito do motim: "são tantos os epiśdios que a elle se ligaram que dificilmente poderemos narral-o". Vamos tentar. ${ }^{7}$

6. Ver para o caso latino-americano alguns dos capítulos de Arrom e Ortoll (1996, esp. caps. 1, 2 e 4). Thompson (1991, pp. 336-351) comenta o uso do conceito de "economia moral" em diversos contextos antigos e contemporáneos, inclusive nāo-europeus, por historiadores e cientistas sociais.
Tudo começou com a publicação de uma postura da Câmara Municipal de Salvador, datada de 12 de janciro de $1857^{8}$, que estabelecia que a farinha de mandioca seria doravante vendida apenas em tuIhas instaladas em determinados locais da cidade, e principalmente no Celeiro Público. Este, espécie de mercado municipal, ficava a beira-mar, na rua do Estaleiro, entre os prédios da Alfândega (hoje o Mercado Modelo) e do hospital da Marinha (hoje Capitania dos Portos). Ali a farinha, que chegava $\mathrm{cm}$ saveiros do Recôncavo e outras regiōes da Bahia e de fora, poderia ser desembarcada e diretamente vendida ao consumidor, sem outros intermediários ou custos adicionais de transporte terrestre. Com a medida, a Câmara pretendia controlar melhor o preço do produto, que andava nas alturas, em parte devido às atividades de atravessadores e monopolistas. A intervenção visava principalmente disciplinar esses comerciantes.

Era entāo presidente da província da Bahia José Lins Vieira Cansanção de Sinimbu, 47 anos, futuro visconde de Sinimbu e chefe de governo de Pedro II, um alagoano filho de senhor de engenho que antes já havia ocupado diversos postos da administraçāo do Império. Fora presidente de Alagoas e Rio Grande do Sul, deputado no parlamento nacional, senador, juiz da comarca de Cantagalo no Rio de Janeiro $\mathrm{c}$ chefe de polícia da Corte. Sinimbu havia tomado posse em agosto de 1856. Nada fez de cficaz para sanar a situação, mas aprovaria a vigência provisoria da postura que proibia o livre funciona-

7. Os relatos básicos (e brevcs) sobre este movimento săo Amaral (1921, pp. 223-227), Ruy (1996, pp. 218-221) e Aguiar (1985, pp. 61-71).

8. Alguns documentos estabelecem 16 e nāo 12 de janeiro. A postura provavelmente foi votada pela cómara no dia 12 e publicada em edital na imprensa no dia 16 de janeiro de 1857. 
mento do mercado de farinha. Não só aprovaria como, um mês depois passou à câmara, a pedido desta, a administração do Celeiro Público, para que fossem coibidos abusos monopolistas que, mesmo ali, sob o nariz das autoridades, se verificavam. ${ }^{y}$

Mas Sinimbu fazia jogo de cena, pois não acreditava na solução da Câmara. De formaçāo européia cultivada in loco, Sinimbu vivera quatro anos em vários países da Europa, onde estudou, escolheu sua futura esposa e provavelmente tornou-se adepto do liberalismo econômico (WILDBERGER, 1949, pp. 370-1). Achava ele que os preços seriam naturalmente pressionados para baixo através da livre concorrência, do mercado livre. E atendendo a reclamaçōes de comerciantes, suspendeu a postura municipal, em 25 de abril do mesmo ano, até que fosse examinada pela Assembléia Provincial, que por lei imperial decidia sobre a legalidade e a oportunidade de todas as posturas munícipais da província. Mas reunidos em outubro de 1857 para discutir a matéria, os deputados não chegaram a uma conclusão definitiva, embora a tivessem aprovado na primeira leitura.

Câmara e presidente já se haviam estranhado antes, em junho de 1857, em torno de uma postura que regulamentava os ganhadores negros ocupados no carrego de gente e objetos. Os negros suspenderam o trabalho por mais de uma semana e Sinimbu, pressionado por comerciantes, obrigaria a Câmara a reformular sua postura (REIS, 1993).

9. Oficio da Câmara para o Presidente, 20.02.1857: e Ofício do Presidente d Câmara, 28.02.1857, APEBa (Arquivo Público do Estado da Bahia), Celeiro público, maço 16tl. A má-vontade de Sinimbu com os camaristas se revela em que demorou uma semana para responder o pedido. E ainda dizia que a administração do celciro seria concedida a lítulo provisório (como a postura era também provisória) e "a fim de coibirem os abusos que, segundo dizem ali praticam". Esse "segundo dizem" denuncia a desconfiança já presente nas relaçōes entre essas autoridades.
Agora em 1858, a disputa contrastava, de um lado, uma visão mais intervencionista do mercado e mais paternalista nas relações entre governo e povo, a noção de que as autoridades deviam proteger os cidadãos contra os especuladores e estabelecer o preço "justo" dos alimentos; do outro lado, o liberalismo de mercado, a doutrina do laissez-faire, a noção de que no final a lei da oferta e demanda por si só regularia os preços e beneficiaria os consumidores.

Em janeiro de 1858, pressionada pelo "clamor da população" (palavras do cônsul inglês John Morgan Jr.), a Câmara entendeu que já se esgotara o prazo para que a postura fosse revogada, e voltaria a editála sem o consentimento do presidente. No ofício a este enviado comunicando a decisão, os vereadores insinuavam ter havido manobras junto à assembéia para a não aprovação da lei municipal. "O assunto", escreveram eles, tinha sido "propositadamente esquecido". Em seguida passavam a denunciar a existência de "um monopólio nos gêneros alimentícios e que este não pode ser destruído pela liberdade de comércio, porque nada vale esta liberdade quando não há e não se pode estabelecer a livre concorrência"." Transformaram assim um documento meramente administrativo num documento doutrinário $e$ político.

Estes mesmos princípios, os vereadores tornaram públicos no edital restabelecendo a postura que mandaram afixar nas ruas e publicar nos jornais da cidade. Ali escreveram que "a ampla liberdade na

10. Citado por Aguiar (1985, p. 62). Num oficio de 25.01.1858, a Câmara apenas informava ao presidente que, tendo vencido o prazo da assembléia, nāo havendo esta revogado a postura, e acreditando que csta "contribuirá necessariamente para fazer baixar o prę̧o desse gênero de primeira necessidade". ela a reeditava, Ver Câmara ao presidente, 25.01.1858, APEBa, Cámaras (1857.59), maço 1404. 
vendagem da farinha de mandioca tem produzido nesta capital um efeito contrário ao desejado, tornando-se evidentemente mais fácil o monopólio deste gênero de primeira necessidade" - um ataque direto ao liberalismo econômico do presidente e um afago ao consumidor aflito com o preço da próxima refeição. Mas, diplomaticamente, os edis afirmavam que a supensão um ano atrás da mesma postura havia sido feita em comum acordo com o presidente, até a tal reunião da assembléia. Tendo esta acontecido sem um veredito final, voltava aquela lei a vigorar, e nos seguintes termos: "toda farinha de mandioca, que se acha para vender em casas particulares pelas diversas freguesias desta cidade, deve ser recolhida ao Celeiro Público dentro de 20 dias [...] devendo ser pela Câmara designados os mais lugares em que tal gênero possa ser vendido"." A notícia, como de costume, correu a cidade de boca em boca, e provavelmente foi motivo de conversas no cais, nas tavernas, alfaiatarias, tendas de barbeiro, oficinas de artesāos.

De acordo com o cônsul britânico, e cle demonstraria com números, a Câmara tinha razão: "Esta medida", escreveu ele, "criou satisfação universal e a consequência foi que a farinha que pela manhā da republicação da Postura da Municipalidade era vendida por $5 \$$ [cinco mil réis] o alqueire, baixou imediatamente para $3 \$ 800$ !"'2 Mas nem isso convenceu o presidente. Sinimbu achava que, diante da indefi-

11. Edital de 25.01.1858 in APEBa, Câmaras, maço 1404. A mesma forma de controle - obrigação de que todas as vendas seriam feitas no mercado público - foi adotada pelo Parlement de Rouen, França, após o motim de 1768. Ver Charles, Louise e Richard Tilly (1975, p. 18).

12. Cónsul John Morgan Jr. para a Legação Britânica no Rio de Janeiro, 3.03.1858, Public Record Office (PRO), Londres, Foreign Office (FO) 13, 365, ff. 62-67. nição da assembléia, prevalecia a suspensão da postura. E no dia seguinte à sua publicação, ele ordenaria ao chefe de polícia que assegurasse aos comerciantes a livre venda da farinha na cidade.

Câmara e presidência passaram um mês trocando farpas, disputando quem mandava no mercado de Salvador. Não sabemos detalhes sobre a repercussão do caso na população, mas a popularidade de Sinimbu não devia estar em alta. É ainda o cônsul britânico quem nos informa que, nesse período, "pasquins eram afixados à noite nas ruas ameaçando a vida do Presidente". ${ }^{13}$ Essa informaçāo sugere a existência de uma oposiçāo organizada, embora noturna e clan. destina, à política presidencial. À luz do dia, a policia entrava em constantes conflitos com os fiscais da câmara, que procuravam obrigar os comerciantes a cumprir a lei municipal. Para cessar os conflitos, Sinimbu escreveu mais um ofício que começava assim: "Ordeno à Câmara Municipal [...] que revogue o seu primeiro edital...". Os vereadores reagiram no mesmo tom, com um longo $e$ insolente oficio, que em resumo dizia: 1) cabia apenas à Assembléia Provincial revogar uma postura $\mathrm{cm}$ vigor $\mathrm{e}$, ao contrário de fazê-lo ela na verdade "a aprovou em primeira discussão"; 2) a tal postura havia sido provisoriamente aprovada pelo próprio presidente Sinimbu, que assim inicialmente reconhecera sua necessidade; 3) a revogação da postura pelo presidente teria como prazo a rcunião da assembléia, que já acontecera desde outubro do ano anterior; 4) o ato do presidente era ilegal, caracterizando abuso de autoridade; 5) ao presidente cabia toda a responsabilidade pelos conflitos entre policiais e fiscais; $\mathrm{e}$ 6) os vereadores recomendavam mais maturidade a Sinimbu, exigindo respeito pelo orgão "que repre-

13. Cônsul John Morgan Jr. para o Foreign Office, 16.03.1858. PRO/FO, 13, 365, fi. 53v. 
senta o povo deste município". ${ }^{14}$ No mesmo dia, 25 de fevereiro de 1858 , o presidente decidiu suspender os cinco vereadores que haviam assinado este documento, substituindo-os por seus suplentes.

Tal era a situação em 28 de janeiro, data da primeira refrega entre a população e soldados a serviço da presidência. Mas o estopim do motim esteve ligado a uma outra ordem de acontecimentos aparentemente sem qualquer ligação com as tensões causadas pela instabilidade do mercado de alimentos e a disputa política entre vereadores e presidente da província.

O dia 28 de fevereiro caiu no segundo domingo da Quaresma de 1858 , tempo de frugalidade da mesa, de jejum. Uma ironia que fosse um dia de food riot. Não foi um domingo pacífico no recolhimento de meninas e moças decentes da Santa Casa da Misericórdia, situado a poucos passos da casa da Câmara e do palácio do governo provincial. Algumas delas seriam punidas com a transferência para conventos da cidade, acusadas de se rebelarem contra a nova administração do recolhimento, passada às mãos das freiras francesas de São Vicente de Paulo cerca de três meses antes. Elas resistiram à punição, houve luta e aparentementc foram agredidas e até feridas pelas irmãs de caridade e membros (homens) da mesa diretora da Santa Casa.

Os gritos de socorro das moças chegaram aos ouvidos de quem se encontrava ouvindo o sermāo quaresmal na igreja da Misericórdia e quem passava pela rua. Essas pessoas foram acudir as recolhidas, que antes do barulho, ao longo das semanas que passaram sob a tutela das francesas, provavelmente já haviam

14. Câmara ao Presidentc, Salvador 25.02.1858, APEBa, Câmaras. 1857-1859, maço 1404. Este documento foi transcrito na integra por Aguiar (1985, pp. 63-66). comunicado a vizinhos, familiares, amigos e pretendentes que andavam desgostosas com o governo das freiras. Estas foram agredidas pela multidāo que invadiu a Santa Casa, mas escaparam protegidas por mesários e outras pessoas - "indivíduos respeitáveis", nas palavras do cônsul inglês - que as levaram ao palácio presidencial, na atual praça Municipal, ou Tomé de Souza, então praça do Palácio.

A animosidade contra as irmās vicentinas disseminou-se pela cidade. Nas imediações da igreja de São José, descendo para a Baixa dos Sapateiros, uma Casa da Providência que dirigiam foi também invadida, mas elas escaparam ilesas para casas vizinhas. Um colégio para moças mantido pelas freiras em Nazaré, um bairro mais distante, seria também as. saltado caso nāo tivesse sido protegido por um piquete da polícia para lá deslocado. A aparente rapidez com que essas açōes tiveram lugar, num raio amplo da cidade, lança a suspeita de que uma ação previamente combinada estava em curso.

Entretanto, a principal arena de conflito naquele dia seria instalada a alguns metros da Santa Casa, na praça do Palácio. Ali reuniu-se uma pequena multidāo para protestar contra as irmãs de caridade e aquele que as protegia, o ocupante do palácio onde elas haviam se refugiado, o mesmo presidente que revogara a postura da farinha de mandioca e suspendera os vereadores que haviam contestado seu ato.

A ligação entre uma coisa e outra não foi difícil de ser feita pelos manifestantes, que passaram a gritar ofensas contra o presidente, inclusive insinuando que cle freqüentava a cama das irmãs francesas (WILDBERGER, 1949, p. 378). Logo reclamavam farinha barata e a reintegração dos vereadores há pouco demitidos. ${ }^{15} \mathrm{O}$ grito por comida ficou simbo-

15. Cônsul Morgan para o Foreign Office, op. cit., fl. 54; Jornal da Buhio, 1.03.1858 
lizado na palavra de ordem que veio a ser a marca do movimento: "queremos carne sem osso e farinha sem caroço". Segundo o relato do Jornal da Bahia (1/3/1858), um cidadão respeitável, João Alves Portella, se pôs à frente do povo e convenceu os soldados a se afastarem. Mas a multidāo decidiu insistir: "e invadiu a casa da Câmara, entrando na sala das sessões, e dando vivas à Câmara e ao Povo, e fora ao presidente; algumas pessoas subiram a torre, tocaram o sino, e depois, descendo dirigiu-se a multidão ao Palácio da Presidência".

O palácio foi apedrejado, vidros das janelas quebrados, um oficial militar ferido. Um soldado atirou e a confusão se instalou. A tropa, inclusive a cavalaria, que a essa altura já havia sido mobilizada, calou baionetas e atacou a multidão, que não pôde fugir do local porque os soldados haviam fechado todas as saídas com o objetivo de impedir a entrada de mais gente na praça. Muitos saíram feridos, alguns gravemente, de um lado pelas pedras retiradas do calçamento e jogadas pelos manifestantes; do outro pelas patas dos cavalos, baionetas e espadas. A certa altura chegou a se esboçar a participação, em defesa dos manifestantes, de um batalhão da Guarda Nacional, o da freguesia de São Pedro, mas foi neutralizado pelo comandante que apelou a seus homens para que não "causassem a sua ruína". ${ }^{16}$ Os ânimos só serenaram com o cair da noite - um comtemporâneo precisou 7 horas (AGUIAR, p. 68) de uma noite clara de lua cheia - , o que significa que o motim, que começara por volta das 3 horas da tarde, durou umas quatro horas. ${ }^{17}$

16. Cônsul Morgan para o Foreign Office, op. cit.

17. Sobre a hora em que começou o motim, o chefe de polícia escreveu: "Ontem de 3 h da tarde em diante...". em seu primeiro e rápido (e segundo ele ainda provisório) relato ao presi.
No dia seguinte novos conflitos ocorreram na praça do Palácio. Naquela segunda-feira, $1^{\circ}$ de março, numa atitude que parecia provocação, o presidente manteve a ordem de se reunirem os vereadores suplentes em sessão extraordinária para o juramento de posse e para contarem os votos das eleiçōes de um certo senador. Sinimbu agia como se nada tivesse acontecido no dia anterior. Às 10 horas já havia uma pequena concentração popular em frente à Câmara e a praça tomada por guardas nacionais $e$ tropas do Exército.

Iniciada a sessāo da Câmara, os populares começaram novamente a gritar contra a carestia e logo ocupavam a sala onde se reuniam os vereadores. $O$ próprio presidente da casa, Joaquim Ernesto de Souza, teria solicitado a presença de força militar para desocupar o prédio e permitir a normalidade dos trabalhos. Sob protestos de que seus direitos de cidadãos estavam sendo ofendidos, os manifestantes se retiraram para a praça. Aqui se repetiram as cenas do dia anterior. Os amotinados foram presos alguns e dispersos outros, alguns empurrados montanha abaixo, outros que escaparam pela ladeira do Pau da Bandeira para evitar uma coluna de soldados que subia da praça do Teatro, atual Castro Alves (RUY, pp. 219-20; AMARAL, pp. 226-7).

Agora formada pelos vereadores suplentes, e aparentemente mais dóceis e livres da pressão popular, a Câmara decidiu se reconciliar com o presidente. $A$ ata da sessão de $1^{\circ}$ de março é eloqüente a este respeito. Declara que a razão daquela sessão extraordinária seria, não contagem de votos de senador como afirma a maioria dos historiadores, mas "dar-se cumprimento à ordem da Presidência, que

dente da províncin em 1.03.1858: APEBa, Polícia, 1858-59, maço 3!39-18. Segundo Masson (1858, p. 16) a noite de 28 de fevereiro foi de lua cheia. 
declarou nulo o edital de 25 de janeiro do corrente ano, que mandou de novo pôr em execução a Postura de 12 de janeiro de 1857 acerca da farinha de mandioca". A matéria foi devidamente posta em votação e a ordem presidencial acatada por unanimidade. Em seguida, para evitar a desconfiança de que teria havido capitulação absoluta, o vereador e tenente-coronel Manoel José de Magalhães introdu. ziu o seguinte requerimento:

"Julgo conveniente a formação de uma companhia cujo prin. cipal fim seja o fornecimento dos gêneros de primeira necessidade pelo preço mais módico possível, requeiro que esta Câmara se dirija a Palácio do Governo afim de tratarmos com sua Exa. o melhor meio de levar a efeito este pensamento".

O que foi aprovado e, ato contínuo, uma comis. são atravessou a praça para reunir-se com Sinimbu e "combinar com sua Excelência sobre a adoção de medidas, que pudessem contribuir para minorar a carestia de farinha de mandioca e outros gêneros alimentícios". A sessão foi suspensa até o retorno da comissão, formada por apenas dois vereadores. Eis o que na volta discursou um deles:

"achava cm sua Exca. o Presidente toda a benevolência, e bons desejos de coadjuvar a Câmara em tāo justo fîn, mas que quaesquer medidas que se houvessem de adotar demandavam calma e refle. xão, que nåo podiam ser tomadas em um momento, ein que os espiritos se achavam agitados pela comoçio popular, que o povo devia descansur e ter confiança no zelo da Municipalidade, e nos bons desejos do Governo, que não poderiam ser outros, senæo o bem e a tranquilidade públicn, pelo que convidava o mesmo povo reunido no salāo da Municipalidade a voltar a suas ocupaçōes ordinárias, confiando na ação da Câmara e do Govemo, que eunpregario todos os esforços que coubessem em suas atribuiçōes para minorar o mal, de que o mesmo povo se queixava". ${ }^{18}$

18. Arquivo Municipal de Salvador (AMS), Alas da Câmara, 1857-61, livro 9.49.
Em seguida os vereadores formalizaram a revogação da postura.

Esta narrativa coloca algumas dúvidas sobre a cronologia dos acontecimentos naquele dia. De acordo com Braz do Amaral, Affonso Ruy e Pinto de Aguiar - que repetem um ao outro — a Câmara já estaria evacuada quando deliberou sobre essa matéria, o que faz sentido à vista da decisão anti-popular que tomara, decisão que dificilmente seria tomada diante de uma multidão amotinada. No entanto, o conteúdo da ata revela que a sala de sessōes ainda estava ocupada pelo "povo" enquanto se desenrolavam a sessão e as negociaçōes - na verdade, a rendição - junto ao presidente. Uma terceira hipótese seria a de que, tendo saído a maior parte dos manifestantes, alguns ficaram. No mesmo sentido, a ata não deixa claro quando se verificaram os conflitos na própria praça, se antes ou depois da sessão da Câmara. É provável que tivesse sido antes.

Seja como for, agora os "representantes do povo" de Salvador estavam divididos. Se os novos vereadores se curvaram à autoridade do presidente, outros o manteriam sob fogo cerrado. Naquele mesmo primeiro dia de março, enquanto os suplentes capitulavam, Manoel Jerônimo Ferreira, juiz de paz da freguesia de Santana e um dos vereadores suspensos, escreveria uma carta dura ao presidente adepto de Adam Smith, acusando-o de ser "somente dominado pelos principios econômicos, que tanto peso têm para V. Exa., e essa liberdade comercial tantas vezes invocada". E advertia:

"so V. Exa. parece adormecido num pequeno círculo de individualidades, que só tratão de si, sem atender ao clamor público, a voz uníssona do Povo, que reclama providências contra o monopólio da farinha e da came verde principalmente, como os primeiros e os mais necessários alimentos da população desta capital. O Povo, Exmo. Sr., nāo vive de teorias, vive de realidades; $e$ quando sabe que não é por falıa de gêneros, ınas simples monopólio que deles fazem alguns homens desalmados [...] nāo podem deixar de praguejar aos causadores de seus sofrimentos; $\mathrm{e}$ é 
entăo o govemo o alvo a que atiram todas as vistas, porque ê no governo que cumpre, por un dos seus mais rigorosos deveres. promover a felicidade do Povo, digo, a felicidade pública, e o bem-estar de seus govemados". ${ }^{19}$

Quanto à interpretação que fizera Sinimbu do aspecto legal $\mathrm{em}$ torno da reedição da postura, 0 vereador o acusaria de estar "falseando todos os princípios da hermenêutica". Mas embora achasse ilegal sua suspensão, Ferreira a acataria para não ter o presidente pretexto

"de exercer vinganças contra os Membros da Câmara, como o fizera ontem e hoje com o Povo inerme, reunido em frente do Palácio de V. Exa., mandando-o dispersar à buioneta e golpes de espada atropelando-o com a força de cavalaria de la. linha, facto novo até hoje visto nesta capital, e que so serve de revelar o mais feroz canibalismo, o rancor e perversidade de queın ordenara scmelhante atentado".

No dia seguinte, Ferreira continuou atacando, agora provavelmente inspirado pelos acontecimentos do dia anterior:

“Na qualidade de Juiz de Paz [...] e cidadāo respeitador das leis do meu Paiz, ameaçado por V. Exa. na minha segurança indi. vidual, como membro da Câmara Municipal, vendo que, com desprezo de todas as Leis, tem V. Exa. estabelecido uma perfeita suspensão de garantias, firmando a mais abominável ditadurs, mandando prender, espancar c recrutar indistintamente a todos os cidadãos, levando o terror ao centro das famílias, e a todos os

19. Carta de Manoel Geronimo Ferreira ao Presidente da Província, 1.03.1858, APEBa Câmaras (1857-59), maço 1404. É interessante que E. P. Thompson (1991, p. 275), respondendo a scus críticos, tenha escrito no mesmo sentido que nosso vereador: os participantes dos food riots "não erain filosofos. Eles realmente [...] tinham argumentos substantivos $\mathrm{e}$ inteligentes sobre o funcionamento de mercados, mas de mercados reais e não relaç̋̌s de mercado téricas". habitantes desta capital, que se acham na mais dolorosa situaçăo. não posso deixar de protestar contra tåo revoltante procedimento $e$ inoudito despotismo de V. Exa., e seus agentes, declarando a V. Exa. responsavel, peronte as Leis do Paiz, por todos esses desacatos e violaçðes feitas a segurança e direitos individuais. garantidos pela constituiçăło política do Imperio".

Rancoroso, despótico, ditador, perverso e até canibal - o vereador Ferreira confrontou o presidente Sinimbu com uma poderosa artilharia verbal. Se Sinimbu lera Adam Smith, Ferreira pode ter lido Diderot, que considerava a liberdade de propriedade em rempos de fome um "princípio canibal". E certamente o era para os pobres de Salvador. Se estes não entendiam de hermenêutica ou economia política, conheciam a linguagem hiperbólica usada pelo vereador, $\mathrm{c}$ a ela acrescentavam a linguagem vulgar das ruas, como chamar o presidente de amante de freira. Zombarias com conotações sexuais contra desafetos e autoridades eram parte da cultura popular da época. Em outubro de 1857, por exemplo, um guarda queixou-se a scu supcrior de que, estando $\mathrm{cm}$ ronda, fora sucessivamente atingido por água suja, urina, casca de jaca e pedra jogadas contra ele de janelas de prédios na rua dos Ourives. Quando ameaçou os agressores de denunciá-los ao chefe de polícia, respondeu um deles, segundo as palavras do pobre guarda, "que não fazia caso do $\mathrm{Illm}^{\circ} \mathrm{Sr}$. Presidente [Sinimbu] conto mas de Chefe de Polícia, que hera muito milhor eu queixar-me a sogra do Alsisbispo". 20" Foi esse tipo de humor popular que foi lançado contra Sinimbu e freiras durante o motim na praça do Palácio no ano seguinte.

20. Francisco Antonio Esteves ao Chefe de Polícia, 22.10.1857, APEBa, Polícia (assuntos). 1857, mą̧o 6481. O texto foi ditado pelo guarda Francisco Esteves, que era analfabeto, a José Maria Pacheco, que linha suas dificuldades ortograficas. 


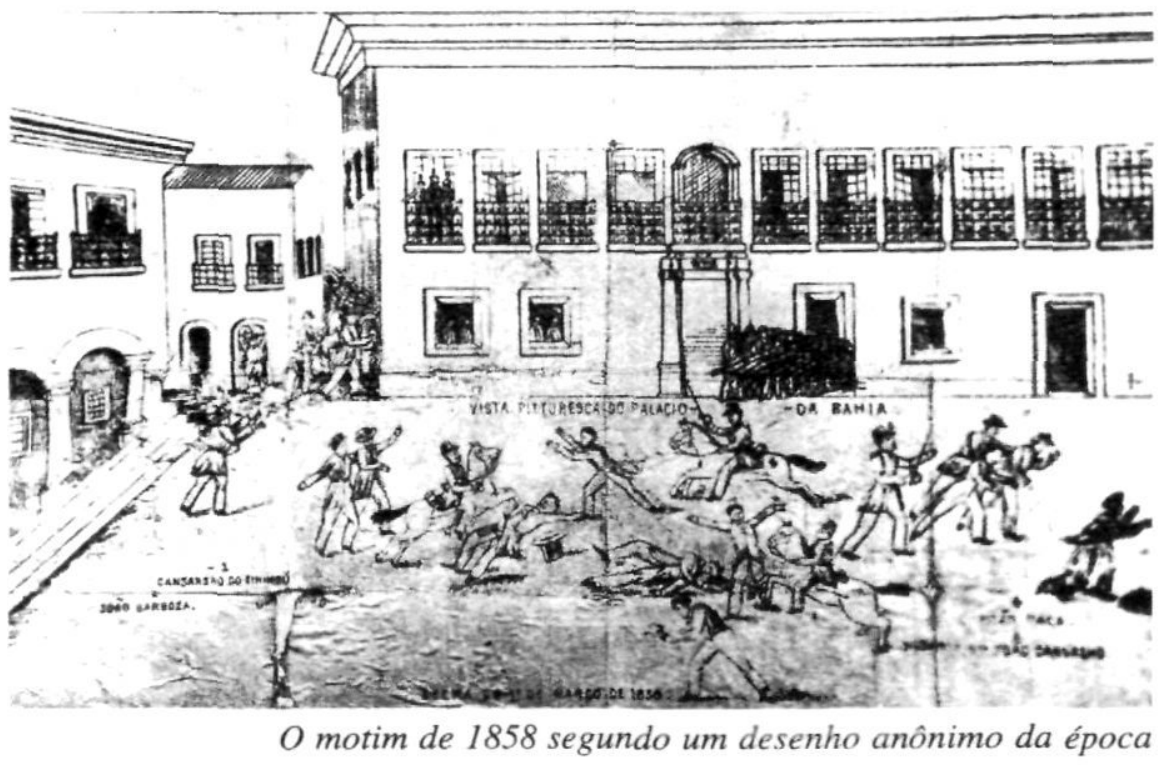

Houve outras leituras críticas e bem-humoradas do poder naquele ano. O desenho intitulado "SCENA DO $1^{\circ}$ DE MARÇO DE 1858 ", feito por um contemporâneo anônimo simpático aos manifestantes, ilustra os acontecimentos na praça. ${ }^{21}$ No fundo, o edifício ocupado por Sinimbu recebe a irônica legenda de "VISTA PITTORESCA DO PALÁCIO DA BAHIA". O palácio se encontra defendido por uma numerosa tropa armada com baionetas. De várias janelas do edifício, pessoas apreciam o desenrolar da repressão aos amotinados. No alto, em uma sacada imediatamente acima da tropa, vê-se uma mulher, mas não parece ser uma freira. É mais provável que o desenhista quisesse representar a mulher de Sinimbu, a alemã Valéria Tourner Vogeler. $\mathrm{Na}$

21. Uma reprodução deste desenho foi publicada por Wildberger (1949, gravura 87). Não conhecemos o original. sacada da extrema esquerda, estão o presidente ladeado por dois homens, todos identificados pela legenda na seguinte ordem: 1. Cansansão do Sinimbu; 2. João Barboza; 3 . nome rasurado na legenda. Infelizmente não conseguimos ainda identificar quem sâo os convidados do presidente, mas suspeitamos que se trate de conhecidos monopolistas. O nome de Barboza, porém, não se encontra no Almanak administrativo de 1858 , que lista centenas de comerciantes de vários ramos e tamanhos.

Em frente ao palácio o desenho representa as cenas de violência promovidas por soldados montados e a pé, comandados pelo capitão Paca, o quarto nome legendado no desenho, e o tenente João Carvalho, o quinto nome. Assim, o artista legou à posteridade sua lista daqueles que via como responsáveis pela "scena" daquele dia, ou como diria o vereador Manoel Ferreira, o "pequeno círculo de individualidades" que cercava o presidente. E confirmou outras fontes quanto às armas usadas na repressão, quando compôs soldados empunhando espadas e 
baionetas e lançando seus cavalos contra os manifestantes. Ao fundo, uma multidāo parece procurar escapar da praça pela estreita rua Direita do Palácio. Voltaremos adiante a este desenho.

O presidente, entretanto, não ficou sozinho. $\mathrm{Na}$ defesa do livre mercado, com ele estava, por exemplo, a Associação Comercial da Bahia, que representava os principais comerciantes da praça de Salvador. À questão colocada por Sinimbu sobre o que fazer para diminuir o preço da farinha, o presidente e o secretário da associação responderam: "Para ser francos [...] não ocorre meio nenhum [...] senão a concorrência entre os diversos vendedores deste arligo". Também desestimulavam o governo a intervir no mercado importando de outras províncias o produto com dinheiro público, porque esta seria a função dos comerciantes, "levados pelo incentivo do lucro". Aliás, sem eles, avaliavam, "teríamos sofrido terrivel fome". Lamentavam a injustiça que a cidade estava fazendo aos comerciantes e, deixavam implícito, ao próprio presidente. ${ }^{22}$

Embora tivesse vencido o motim e a Câmara, Sinimbu logo partiria para a Corte, dando a impressão de que, ganha a batalha perderia a guerra. Felizmente, para ele, deixaria Salvador antes de 2 de julho, que segundo o cônsul inglês reunia anualmente cerca de $50 \mathrm{mil}$ pessoas nas ruas para celebrar a Independência da Bahia. O cônsul revelou, em 16 de março, que tinha informaçōes de que se estava recrutando gente do povo para um levante nesse dia. Segundo o cônsul, o Dois de Julho era uma celebração hostil aos portugueses e, por extensāo, corriam perigo todos os estrangeiros - naqueles dias sinô-

22. Manoel Belens de Lima e Jođ̃o Cezimbra para o Presidente da Província, 3.03.1858, APEBa, Câmaras, maço 1404. Ver também Ridings, Jr. (1970, pp. 130-135). nimo de mercadores e ... freiras francesas e presidente alagoano. "Eu temo", escreveu ele, "que a vida mesma do Presidente sofrerá um atentado se a ocasiāo permitir". ${ }^{23}$ Duas semanas antes, ele também temia por sua própria vida, e pedira ao representante britânico no Rio que enviasse um navio de guerra para defender os ingleses na Bahia, a quase totalidade dos quais era comerciante e portanto alvo potencial do descontentamento popular. ${ }^{24}$

Um atentado contra a vida de Sinimbu realmente teve lugar em 25 de março. Ele foi ferido com um tiro quando presidia da sacada do palácio a manobras militares em comemoração pelo juramento da constituiçāo do Império, "Dia de Grande Gala", segundo definição do calendário oficial. Dois meses depois Sinimbu deixaria o governo, embarcando no navio para o Rio de Janeiro sob a proteção de tropas (WILDBERGER, pp. 378, 380).

\section{Os participantes do levante}

Nas curtas narrativas até agora escritas sobre o assunto, existem poucas pistas indicando o perfil social dos envolvidos no motim de 1858 . Fala-se genericamente de "plebe", "povo", "populacho". Os documentos da época, apesar de carregados de imagens distorcidas, mapearam de uma forma mais precisa aquilo que os historiadores depois simplificariam.

O observador contemporâneo que talvez tenha sido mais detalhado $\mathrm{em}$ descrever a composição social dos manifestantes foi o cônsul inglês John Morgan. Por exemplo, ao contrário dos testemunhos locais, que nunca mencionam a cor dos participan-
23. Cônsul Margan para o Foreign Office, 16.03.1858, op. cit..

24. Cónsul Morgan para a Legação Britânica no Rio de Janeiro, 3.03.1858, op. cit. 
tes, o cônsul insistiu exatamente neste ponto nas duas cartas que escreveu relatando o epiś́dio. Numa delas afirmou que "os preços de fome" dos alimentos básicos provocaram "o levantamento dos espíritos da grande população livre de cor", levando-a a praticar "excessos". Numa outra passagem condenava como absurda a idéia do presidente Sinimbu de "pregar os princípios do mercado livre para uma população de cor ignorante". Racista, Morgan julgava que o superior princípio do livre comércio só podia ser entendido por povos superiores, brancos, como os europeus, como ele. Escrevendo diretamente sobre os protagonistas dos episódios de 28 de fevereiro, ele os rotulou de "uma massa composta exclusivamente das ordens baixas" da cidade. Utilizou também termos mais sintéticos, imprecisos e pejorativos, como "populacho" ("populace"), "turba" ("nob") e "massa" ("mass"), praticamente sinônimos, que não acrescentam muito mas revelam uma certa sintonia terminológica entre o inglês, seus contemporâneos da elite brasileira da época e historiadores mais recentes. ${ }^{25}$

Uma autoridade policial, por exemplo, informou ao presidente da província, em $1^{\circ}$ de março, que as "pessoas do povo" amotinadas "se compunha[m] de gente da baixa classe", sem nenhuma menção à cor da classe. Em abril uma outra autoridade escreveria que haviam sido presos praticamente todos os indivíduos que "maltrataram as Irmās de Caridade". Adiante escreveria que as "cenas de selvageria" foram protagonizadas "por uma centena do que a população desta cidade tem de mais desprezível e ordinária". Eram "delinqüentes", definiu. E os contras-

25. Cônsul Morgan para o Foreign Office, 16.03.1858, op. cit; Cónsul Morgan para a Legação Brilânica no Rio de Janeiro, 3.03.1858, op. cit. tava com a "parte boa e sensata da população", que ficara do lado das irmãs e não se envolvera nos distúrbios de rua. ${ }^{26}$

Vamos retomar o que disseram as autoridades policiais: quem era aquela "gente da baixa classe", aquela parte "mais desprezível e ordinária" da população de Salvador? Na sua maioria a gente pobre negra e mestiça, livre e escrava, descrita a cores pelo inglês. As estimativas da população da cidade nessa época variam grandemente, entre 58.498 , segundo o censo de 1855 (NASCIMENTO, p. 65), e 140 a I 50 mil, conforme o Jornal da Bahia (9.02.1857). Em 1858 Salvador era uma cidade de muitos pobres, numa proporção que pode ter alcançado 90 por cento, segundo estimativa de Katia Mattoso (1978, pp. 234-5 e n. 477). A concentração de riquezas era grande. De uma amostra de 395 pessoas cujos bens foram inventariados após morrerem entre 1800 e 1850 pessoas que portanto tiveram bens para deixar-, as 10 por cento mais ricas controlavam 67 por cento da riqueza e as 30 por cento mais pobres apenas 1 por cento (REIS, 1986, p. 23).

Os realmente miseráveis eram numerosos. Walter Fraga Filho (1996), que fez um estudo cuidadoso sobre o assunto, identificou 33 pontos de mendicância na área central de Salvador no século XIX, cerca de dez próximos ao teatro de agitações em 1858. Na década de 1850, o poder público já desenvolvia uma forte campanha de repressão à mendicância $e$ iniciava o confinamento dos mendigos em abrigos afastados do centro da cidade. Em 1857, um administrador do Asilo de Pobres escreveu que o objetivo era "trazer a pobreza $\mathrm{cm}$ boa ordem, não consen-
26. Justiniano Baptista Madureira ao Presidente da Provincia, 1.03.1858 e Lopes Leão ao Presidente da Província. 24.04.1858, APEBa, Polícia. 1858-59, maço 3139-18. 
tir desordem". ${ }^{27}$ Mas contando com redes próprias de sociabilidadè, com estratégias de sobrevivência consagradas pelo costume, com relaçōes de apoio na comunidade, cles resistiram e continuaram a compor o tecido social da cidade. Quanto ao perfil racial dos mendigos em meados do século, apenas 14,8 por cento eram brancos - que representavam $32,4 \%$ da população e portanto estavam sub-representados entre os mendigos - , sendo os demais africanos, crioulos (negros nascidos no Brasil) e mestiços (FRAGA FILHO, pp. 55, 67, 68 e caps. 6 e 7).

Ao contrário do que informou o cônsul inglês, houve participação de escravos no movimento. Dos 53 presos que encontramos nos registros policiais, quatro eram claramente identificados como escravos, todos pardos. Acreditamos poder acrescentar a estes presos outras onze pessoas registradas sem sobrenomes, como sendo escravos. Assim, 21 por cento dos presos eram cativos, entre os quais apenas dois africanos. Os da África, tanto escravos como libertos, em geral não entravam em movimentos dominados pelos nacionais. Conspiravam, rebelavam e até faziam greve sozinhos (REIS, 1986 e 1993). Salvador ainda era, $\mathrm{em}$ 1858, uma cidade onde 30 a 40 por cento da população cra formada por escravos, integrados à economia urbana como carregadorcs, artcsãos, domésticos etc. Na freguesia da Sé, a mais populosa e onde se desenrolaram os acontecimentos aqui narrados, a presença de escravos era menor, 18,8 por cento segundo o censo de 1855 , índice proporcional àquele dos presos escravos. Mas considerando todos os residentes - escravos, libertos e livres —, os chamados "de cor" representavam 66 por cento da freguesia (NASCIMENTO, 1986, pp. 71, 95).

27. Manocl Alves de Sá para o Chefe de Polícia, 24.11.1857, APEBa, Polícia, maço 6481 .
Entre escravos e livres ou libertos, 17 (ou 32\%) dos 53 presos de 1858 tinham aquelas características raciais: seis pardos, cinco cabras, quatro crioulos e os dois africanos. Considerando o nome que tinha, um certo Afro José pode ser incluído como o $18^{\circ}$ nome da lista dos não-brancos presos. Nenhum branco aparece racialmente identificado, o que pode significar que fossem até maioria entre os presos. Os brancos tinham sua cor raramente registrada em documentos de ocorrência policial, exceto nos inquéritos. Registrar apenas a cor dos descendentes de africanos servia como um mecanismo a mais de desclassificação social, um ritual de controle e de confirmação da subalternidade. ${ }^{28}$

Mendigos, pobres, escravos formavam a "classe perigosa" da Bahia de então. Destes segmentos da população provavelmente saiu a maioria dos participantes do movimento de 1858. Mas é possível que gente um pouco melhor situada também tivesse aderido. No desenho que apreciamos há pouco, algumas das pessoas atacadas pelos soldados estão vestidas com roupas decentes, inclusive usam cartolas, além de estarem calçadas. Este último dado é particularmente importante porque o motim ficou também conhecido na tradição oral como "revolta dos chinelos", devido a que na correria para escapar da repressāo, os manifestantes perderam seus chinelos, abandonando-os às centenas na praça. ${ }^{29}$ Essa men-

28. Ver as "Panes da Polícia" para o ano de 1858 in APEBa, Polícia. 1858.59. maço 3139-18.

29. Não encontramos nada na documentaçāo escrita que confirmasse csta versão, presente nas narrativas sobre o epiśdio desde Braz do Amarat. Acreditamos que tanto esta informação como a que trata da reivindicação de "came sem osso e farinta sem caroço", tamberm inexistente com esıas palavras na documentação consultada, se incorporaram a memória histórica da cidade através da tradição oral. 
ção ao calçado típico dos pobres livres - os escravos em geral andavam descalços - confirmaria as fontes escritas quanto à composição social predominante da revolta. Mas estas fontes podem todas estar conspirando para caracterizar desta forma o movimento com o objetivo de diminui-lo, uma vez que na mentalidade da elite da época não cra importante o que não fosse protagonizado por gente importante. O objetivo do desenhista de dignificar o movimento se encaixa nesta mentalidade, daí ter ele representado conspicuamente indivíduos com aparência mais afluente. Mas ele nāo representou só eles.

$O$ artista anônimo é a única fonte que se refere à participação feminina na manifestação da praça. No canto direito de seu desenho ele traçou uma mulher negra correndo dos soldados. Ela usa pano da Costa e torço na cabeça, tendo a sua frente um tabuleiro. Não é de duvidar. As mulheres negras cram personagens destacadas das ruas da Bahia oitocentista, por onde circulavam ocupadas nos mais diversos afazeres, carregando água, trouxas de roupa, comprando e sobretudo vendendo $\mathrm{em}$ tabuleiros bem cquilibrados sobre a cabeça. A que aparece no desenho é uma ganhadeira, que podia ser uma das centenas de escravas e libertas dedicadas à venda de comida crua ou cozida. Elas nāo tinham muilo porque defender a Câmara municipal, já que eram sistematicamente perseguidas por seus fiscais, incumbidos de multá-las por desobediência a alguma das muitas posturas que regulamentavam a vendagem nas ruas (SOARES,1994, cap. 2). No cntanto, naquele dia podiam estar na praça como consumidoras, a exigir comida barata.

As mulheres das classes populares foram presença constante nos motins desse tipo na Europa, o que tem sido explicado como expressão de seu papel na cozinha, cuidando da comida da família, e no mercado, comprando essa comida. Daí os aumentos de preços e a sonegação da oferta dos produtos por especuladores serem assuntos direlamente relacionados com o universo feminino. Estudos recentes têm su- gerido que elas também trabalhavam fora de casa, sobretudo nas cidades "proto-industriais" inglesas de médio porte. ${ }^{310}$ As negras na Bahia faziam tudo isso: trabalhavam na rua e em casa, compravam e ainda vendiam. Estavam portanto antenadíssimas nas oscilações do mercado. Não é então estranho que tivessem agitado a praça, embora com participação minoritária. Mas o único indício disso, repetimos, é aquele desenho.

Pode-se dizer com alguma justiça que as recolhidas da Santa Casa também contaram no movimento. Sem elas é possível que o episódio nem tivesse acontecido, pois foram a faísca inicial. Mas ao contrário das ganhadeiras negras, mulheres das ruas, elas eram mulheres de casa. Mais ainda: da Santa Casa. O recolhimento tinha sido fundado no início do século XVIII como mais um empreendimento caritativo da Santa Casa da Misericórdia, para abrigar moças orfãs e internas, que ali viveriam honradamente, se educariam em prendas domésticas e consolidariam uma formação religiosa. Dali sairiam com dote para casar. Por muito tempo o ingresso ficou restrito a mulheres brancas de famílias cristãs velhas, nem sempre pobres, mas em meados do século XIX as regras já eram outras. Em 1858 elas eram 104,

30. Sobre a participação feminina em food riots na Europa, ver Perrot (1988, pp. 192-195): Stevenson (1979 pp. 101-2), e principalmente os estudos especificamente sobre o tema de Maurin (1988) e Béliveau (1988). Ver ainda Bohstedt (1988), que contesta autores que sustentam a predoininância das mulheres nos fond rioss, inas constata que elas participaram de pelo menos metade dos casos por ele estudados. Uma crítica muito boa do uso de fontes por Bohstedt, e outros aspectos de seu arigo, é feita por Thompson (1991, pp. 305-336). Na Bahia, as mulheres também participaram da revolta da Cemiterada, que como a de 1858 começou com pedradas na praça do palácio: ver Reis ( 199 !. pp. 329-330). 
sendo 50 brancas, 33 pardas, 16 cabras e 5 pretas. As não-brancas representavam maioria, embora em proporção menor da encontrada na população de Salvador. Quanto a idade, 18 estavam na faixa de 1 a 10 anos, 61 entre 11 e 20, 19 entre 21 e 30, 4 entre 31 e 40 e duas com mais de 40 anos (NASCIMENTO, 1992; ANDRADE, 1992). Este é o que por hora podemos dizer do perfil das moças rebeldes, destacando serem na maioria "de cor" e adolescentes.

Retornemos à rua. Conheçamos mais de perto alguns dos presos por participação no motim. Justiniano Barbosa Porto, por exemplo. Como a maioria dos

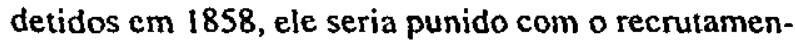
to para serviço militar. Lembramos as palavras do vereador aí atrás, de que Sinimbu mandara "prender, espancar e recrutar indistintamente a todos os cidadãos". Fica confirmado que o poder enquadrara os rebeldes como vadios, que eram tipicamente punidos com o recrutamento. Uma puniçẩo e tanta: a vida da caserna era dura - comida pouca, maus-tratos e sobretudo o risco de servir em outras províncias. Quando avisados da aproximação de patrulhas de recrutamento, os homens mais jovens desapareciam de circulação nas vilas e bairros. Se presos, até provarem que trabalhavam, que eram casados e/ou tinham fithos, que eram arrimo de família - algumas das condiçōes que legalmente evitavam o recrutamento eles já podiam estar servindo nas fronteiras do país. As famílias que rezassem para tê-los de volta vivos. Daí o vereador também ter acrescentado que Sinimbu estava "levando o terror ao centro das famílias". O recrutamento era uma forma de controle social e político, e assim foi usado em 1858. ${ }^{31}$

31. Ver sobre recrutamento na Bahia Hendrik Kraay ( 1995. cap. 6), que no entanto demonstra uma ampla cumplicidade de vários setores da população com o recrutamento.
Nosso personagem, Justiniano, foi mandado para - Exército. Era filho bastardo de Eustáquio Manoel José Porto, que reclamou a sua soltura alegando ser ele trabalhador e portanto isento do serviço militar. Embora morador na distante freguesia da Penha, praticamente um subúrbio de Salvador naquela época, ele esteve na peleja no centro da cidade, conforme a acusação de um inspetor de quarteirão de sua freguesia. Eis as palavras deste sobre Justiniano, em ofício a um subdelegado:

"embora trabalhe algumas vezes de carpinteiro, $c$ bastante vadio, é solteiro, năo é guarda nacional, diz ser matriculado na Capitania do Porto, sem ser maritimo, e somente para se evadir de ser guarda nacional, ocorrendo mais ser um dos que foi na noite do dia 28 de fevereiro para o barulho da praça; como se gaba aqui publicamente, e que já o nāo prendi por ter estado alguns dias oculto por este motivo". ${ }^{32}$

Justiniano desfrutava um modo de vida que, neste período, começava a preocupar a elite: a vida de trabalhador intinerante, biscateiro, $\mathrm{c}$ cheio de malícia para evadir-se das obrigaçōes legais - como os cmbarcadiços estavam isentos de servir na Guarda Nacional, Justiniano se matriculara no porto. Walter Fraga (1996, caps. 4 e 8) mostra que esse estilo de vida foi aos poucos sendo enquadrado como vadiagem ao longo do século XIX, dentro dos objetivos do Estado de controlar as ruas e forçar a crescente população livre a se engajar em ocupaçōes produtivas estáveis. Uma das dimensöes políticas desse tratamento dispensado aos pobres era precisamente dificultar a ocorrência de distúrbios como os de 1858. E o carpinteiro não só se amotinara, como jactava-se de havê-lo feito, dando um mal exemplo.

32. Inspetor José Pedro de S...ao subdelegado Henmenegildo Pereira de Almeida, 19.03.1858, in APEBa, Policia, 'mą̧o 3139-18. 
Por isso devia receber punição igualmente exemplar. Em seu despacho a respeito de Justiniano para o chefe de polícia, o subdelegado aumentou a história de seu inspetor dizendo ter o vadio tomado "grande parte na sedição". ${ }^{33}$ E assim o Exército ganhou mais um soldado.

Pelo menos um soldado de artilharia, um guarda urbano $\mathrm{c}$ um guarda nacional tomaram o partido dos sediciosos em 1858. O soldado, Fortunato Gomes de Almeida, preso em flagrante, foi embarcado para servir na Armada Imperial (Marinha), apesar da interferência de seu comandante pedindo sua soltura por ter ele "conduta militar boa". ${ }^{34} \mathrm{O}$ guarda urbano era José Victor de Moura, homem mais maduro, com idade acima de 40 anos, e casado. Ele seria demitido dos quadros da polícia e também enviado para a Armada "pelo seu mau procedimento durante os movimentos dos dias 28 de fevereiro e $1^{\circ}$ do corrente", escreveu o chefe de polícia ao presidente, que lhe consultara sobre uma petição de José Victor. Este alegava ser casado e pai de três filhos menores, e se considerava devidamente punido por já se encontrar atrás das grades há ccrca de dez dias, pois "a sua falta nāo foi contrária à ordem pública e apenas gracejos fora da presença do Ilmo. Sr. Dr. Chefe de Polícia". Infelizmente não sabemos que gracejos foram estes, nem se o pobre José Victor se livrou do serviço militar. Registre-se que o serviço na Marinha significava, mais do que no caso do Exército, o afastamento de casa, freqüentemente para

33. Subdelegado Hermenegildo Pereira de Almeida ao Chefe de Polícia, 20.03, 1858, in APEBa, Polícia, maço 3139-18.

34. Comandante Antonio José de Lima ao Presidente da Província, 5.03.1858, APEBa, Guarda Naciomal, maço 3589: Justiniano B. Madureira ao Presidente da Provincia, 30.03.1858, APEBa, Policio. 1858-59. maço 3139-18. o Rio de Janeiro. Foi o que aconteceu a Afro José: "sendo inspecionado de saúde, e julgado bom, foi, com outros, remetido para a Corte", lê-se num ofício do chefe de polícia. ${ }^{35}$

O guarda nacional desse grupo, Pedro José de Santana, teve um papel de liderança no ataque às freiras francesas. Segundo Braz do Amaral (1921, p. 225) ele era "cafuz"- mestiço de negro e índio e morava na distante freguesia de Brotas, em cujo quinto batalhão da Guarda servia. Segundo um relato da época, Pedro José

"armado com uma tranca dera o assalto na casa das Irmãs de Caridade a Baixa dos Sapateiros, subindo pela biqueira da mesma propriedade, violando assim aquele estabelecimento com o major escândalo, e concorrendo com semeihante procedimento para que outros mais o seguissem, do que resultou essa sedição que tivera lugar nesse dia, e no seguinte." 36

A importância desse depoimento está em ser o único que identifica um líder do povo rebelde naqueles dias. Infelizmente nāo sabemos mais sobre ele. Já que fazia parte da Guarda Nacional, Sañtana não era mendigo ou "vadio", devia ter alguma ocupação, era um "cidadão". Mas cidadāo de terceira classe porque, embora pudessem compor esta força, pretos e pardos cram sistematicamente alijados do seu quadro de oficiais. De qualquer sorte, ele pertencia a um corpo militar que, por não ser profissional, estava mais próximo das angústias da sociedade civil. A Guarda podia agir prontamente em nome da ordem, como fez amiúde na Bahia das décadas de

35. Justiniano B. Madureira para o Presidente da Província, 13.03.1858 e 20.04.1858, in APEBa, Policia. 1858-59, maço 3139-18.

36. Tenente Coronel José d'Araujo ao Presidente da Província, 03.03.1858, APEBa, Guarda Nacional. ınaço 3589. 
1830 e 1840, mas podia ter seus momentos de vacilação, como acontecera agora $\mathrm{em} 1858$ no quase confronto com as forças de primeira linha no primeiro dia de protestos. E é possível que, além de Santana, outros guardas tivessem participado dos distúrbios populares desse ano, conseguindo manter-se no anonimato. Quanto à sorte de Santana, por enquanto s6 sabemos que dois dias após os conflitos estava preso no guartel da Palma. ${ }^{37}$

\section{Carestia, motim, cidadania}

Mesmo considerando que motins contra a carestia nāo sejam uma resposta imcdiata e mecânica do povo à fome, geralmente eles aconteciam em conjunturas de alta de preços. A década de 1850 na Bahia foi um desses períodos, o que se comprova tanto através das estatísticas de preços, como pelas repetidas queixas $\mathrm{e}$ rcivindicações salariais de indivíduos e grupos pressionados pela carestia. A siluação se agravou nos últimos três anos da década.

Os grupos mais atingidos pela crise não se acomodaram, $e$ antes do motim muitos tentaram achar uma saída através de canais convencionais. Em 1857 58 . Sinimbu seria bombardeado por pedidos de aumento salarial de diversos grupos de operários e servidores civis e militares a ele subordinados. O Estado era na época o principal empregador urbano de trabalho assalariado, numa cidade praticamente sem indústrias e ainda decisivamente dependente do trabalho escravo. Em fevereiro de 1857, os operários do Arsenal da Marinha pediram mais salário, "visto a carestia dos gêneros alimentícios, afim de que melhor se possam manter com suas famílias", conforme re-

37. Idem. Sobre a Guarda Nacional, ver Castro (1979); e sobre a participaçāo (e a discriminaçảo) dos negros ncsta força, ver Castro (1969). lato do administrador. Um guarda do arsenal, pai de cinco fillhos, queixava-se de não poder mandar os dois mais novos para a escola por não ter com que vestílos, vez que seu salário era consumido pela "carestia dos gêneros alimentícios". Cinco meses depois, o comandante das armas da Bahia dizia ao presidente ser impossível a seus soldados, "enquanto durar semelhante crise", viverem do soldo estipulado pela tesouraria provincial. Ele falava da carestia. Até um guarda do Cclciro Público, em cuja ocupaçāo podia melhor barganhar por comida barata, nāo se esquivou de pedir aumento salarial, em outubro de 1857, "à vista do preço elevado dos gêneros alimentícios presentemente". Em fevereiro de 1858 os cornetas e tambores da Guarda Nacional, diante da "mesquinhez dos [seus] vencimentos", escreveram pedindo aumento porque "os gêneros de primeira necessidade têm subido a um preço exorbitante".3.

Várias outras categorias do funcionalismo público - servidores da Câmara Municipal c da Assembléia Provincial, da Tesouraria, da Secretaria da Presidência, vacinadores, professores etc - foram se queixar aos deputados. No início de 1857, há apenas alguns meses da passagem do cólera pela cidadc, os professores cscreveram:

"Se em tempos de abundância, malíssimamente podiam subsistir os Suplicantes com o ridiculo ordenado de $400 \$$ [quatrocentos réis], que farảo na presente c calamitosa crise. en que dois terríveis inimigos (peste e fome) nagelam o povo? ${ }^{39}$

38. Diogo Pavon para o Presidente da Província, 12.02.1857, APEBa. Militures, maço 3250; Solidoro Lago para o Presidente da Provincia, 8.06.1857,APEBa, Militures, ınaço 3391; Manoel de Sá Freire para Asscmbleia Legislativa (que encaminhou a pelição ao Presidente da Província), 26.10.1857, A PEBa, In.spesor da Tesouraria, maço 4260; Petição dos Cornetas e Tambores ao Presidente da Província, 10.02.1858, APEBa, Guarda Nacional, maço 3589.

39. Ver várias petiçōes em APEBa, Legislativo, ınaço 984. 
Os guardas municipais fizeram coro em junho de 1857:

"pobres como são e onerados de familias que têm por obrigação sustentá-las [...] e sujeitando-se por isso os mesmos suplicantes a esse pesado trabalho de pedestre com o fim de [...] poder manter-se e a suas infelizes famílias, nāo o podem fazer com o que atualmente percebem. $V$. Sas. sabem muito bem o estado em que se acham os viveres, e por isso também conhecem que $500 \$$ não podem os suplicantes sustentarem-se mais suas famílias..." 40

Uns pediam aumento salarial, outros emprego, outros anistia fiscal. Em setembro de 1857, José Libório Nunes de Carvalho tinha mãe sexagenária para cuidar, e ainda herdara, do irmāo recentemente morto, "a desvalida viúva com duas orfansinhas". Ele pedia à Assembléia Provincial o lugar de contínuo que havia pertencido ao irmāo, alegando a "época tão excepcional como a que vivemos". Mas o emprego já tinha sido dado a outro. Dois meses depois, três irmās pediram dispensa das multas por atraso no pagamento da décima urbana - o imposto predial da época -, e permissāo para saldar a dívida em prestações. Alegavam dificuldades diante da "terrível crise atual da carestia dos gêneros de primeira necessidade". O pedido foi indeferido. ${ }^{41}$

A crise era com frequêencia tratada pela imprensa. Longe estava o tempo quando o Brasil tinha sido visto como a terra da abundância, lamentava um editorial do Jornal da Bahia (23.05.857). "O Brasil de nossos dias", continuava, "já não é a terra abençoada da Sancta Cruz, de ameno clima, de saudáveis ares, que atraia e fazia a inveja ao estrangeiro". E concluía: "Vivemos um tempo de verdadeira lucta contra a miséria, lucta contra a fome".

40. Petiçāo dos Pedestres à Câmara (1857), APEBa, Câmara, maço 1403.

41. APEBa, Legislativa. Petiçües, maço 1047.
Diante de depoimentos tão eloqüentes - e poderíamos preencher várias páginas com outros seria dispensável conferir os números da crise, vez que vale mesmo o que estava na mente da população no tempo do motim. Mas, por disciplina acadêmica, vamos aos números. Os estudos de Katia Mattoso (1992, pp. 364-5; 1978, pp. 368-70) confirmam que esse período realmente foi de alta nos preços de farinha de mandioca, carne verde, carne seca, toucinho, aves, feijāo, entre outros produtos. A situạ̧̧ão no ano do motim havia piorado consideravelmente. Um pedreiro, que em 1854 gastava 47,3 por cento de seu salário na compra de farinha, feijāo e carne verde, gastaria 58,5 por cento em 1858. Mas, como explica a autora, a grande maioria dos trabalhadores livres e escravos de Salvador na época não tinha emprego estável, nāo era a rigor assalariada. Enfrentava despreparada uma conjuntura em que os preços da farinha e da carne haviam dobrado nesses quatro anos.

Às vésperas do motim, em 1857, o preço da farinha de mandioca alcançara o primeiro grande pico da curva de preços nominais no século XIX. Se, quando deflacionado, ele diminui em relação a outros periodos de escassez - como por ocasião da Guerra dả Independência (1822-23) - confirma-se uma elevação substancial do preço real entre 1855 e 1857. Os preços deflacionados também indicam uma situação relativamente estável no longo prazo (BARICKMAN, 1991, pp. 232, 264-6). Exatamente por isso, altas repentinas angustiavam o consumidor porque ele contava poder sempre ter na mesa pelo menos esse produto básico de sua dieta, o "pão da terra".

A crisc de abastecimento e flutuaçōes selvagens, embora de curto prazo, no preço da farinha não eram coisa nova. Desde o final do século XVIII, com a expansão da agricultura de cxportação - leia-se cana-de-açúcar e secundariamente fumo - o cultivo da mandioca fora desprezado. As queixas a este 
respeito inundam a documentação referente à primeira metade do século XIX. Mas um estudo recente de Bert Barickman (1991) sugere que tanto o Recôncavo - em especial a regiāo de Nazaré das Farinhas - quanto as vilas do sul da Bahia - Caravelas, Alcobaça, Rio de Contas, Valença e outras- mantiveram a cidade razoavelmente abastecida a longo prazo. Durante os anos de crise, a Bahia lançava mão de outras províncias, algumas distantes, como Santa Catarina, cuja farinha $\mathrm{em}$ vários momentos veio a alimentar os habitantes de Salvador. Em 1857, as três províncias que mais abasteceram o mercado baiano foram Espírito Santo, Rio de Janeiro e Santa Catarina, nesta ordem, de onde se importaram, entre janeiro e setembro, 207502 alqueires do produto, insuficientes para reprimir o preço. ${ }^{42}$

Não nos foi possível estabelecer a quantidade de farinha necessária para abasteccr o mercado de Salvador a preços razoáveis. De qualquer forma, a farinha que vinha de fora não era barata e a Bahia a disputava no contexto de um mercado nacional. Santa Catarina vendia sua farinha ao Rio de Janeiro, que era também importante produtor, a um preço bem maior do que na Bahia se podia pagar. A se confiar na avaliação da Associação Comercial, nāo se podia vender aqui farinha importada a um preço menor do que o encontrado nas próprias regiōes produtoras, salvo se subsidiada pelo governo. ${ }^{43}$

A alta de 1857-58 foi atribuida por contemporâneos e historiadores recentes principalmente a uma terrível seca, que se prolongaria até 1861. Mattoso (1992, p. 566), no entanto, avisa: "Na verdade, as

42. Manoel Maria do Amaral para o Presidente da Província, 21.10.1857, APEBa, Tesıuraria. Inspetor, maço 4260.

43. Belens e Cezimbra para o Presidente da Província, 3.03.1858, op. cit.. variaçōes de preço nunca sāo determinadas por um único fator", escreveu. Ela lembra, por exemplo, que dois anos antes do motim a Bahia havia sido duramente atingida pela epidemia de cólera, coisa que os contemporâneos também listavam como um dos fatores da crise. Mas não se conhece ainda quanto a desorganização dos sistemas produtivo e de abastecimento durante a peste se projetou sobre 1857-58. O 6timo estudo de Onildo David (1996) sobre a epidemia sugere que a Bahia recuperou rapidamente sua capacidade anterior de abastecimento, tão logo cessara a mortandade epidêmica. Pois se esta ceifou vidas de lavradores que deixaram de plantar, também ceifou vidas de consumidores que deixaram de comer.

Embora de difícil mensuração, um elemento sempre lembrado como responsável pelo aumento de preços da farinha e outros produtos alimentícios seria a especulação, que como vimos fora o principal alvo de ataque da Câmara Municipal. As queixas vinham de longe. Cinqüenta anos antes, em 1807. um almotacé chamava de especuladores a lancheiros que pediam isenção de impostos: "têm o costume de andar nas embarcaçōes a fretes, atravessando e revendendo os mantimentos".44 Durante o período imperial, as vilas da província sem exceçāo criariam posturas contra a ação dos atravessadores de alimentos. Em 1829 Santo Amaro punia os "atravessadores e monopolistas" com a alta multa de $30 \mathrm{mil}$, confisco da mercadoria e prisão. ${ }^{45}$ Em 1830, a Câ-

44. Juiz Almotacé Antonio Xavier da Silveira ao Senado da Câmara, 30.05. 1807, APEBa, Legislativa. Oficios do Senado da Câmara, 1807 (ñ̃o catalogado na época em que foi feita a pesquisa).

45. Ver documentos na Seção Legislativa do APEBa, em tāo grande número que seria tedioso reproduzir. 
mara de Salvador indeferiu - contra a opiniāo do presidente da província, o que mostra uma história mais longa de discordância entre os dois poderes neste ponto - a petiçāo de um comerciante que desejava abrir uma armazém onde venderia farinha, feijāo, milho e arroz. Também naquela época os vereadores só permitiam a venda no Celeiro Público - ou, em pequena quantidade, nos armazéns "a fim de não monopolizarem". Em 1836, num diagnóstico sobre a carestia da carne feito pela Câmara a pedido da Assembléia Provincial, foram apontados como responsáveis as secas e os conflitos sociais nas províncias fornecedoras, Piauí e Goiás, mas os especuladores ganharam destaque porque aceleravam suas atividades em tempo de escassez. "Escandaloso monoṕlio", escreveram os vereadores, acrescentando: "sabe-se que ou todo o gado é comprado pelos atravessadores na porteira das fazendas, passando-o progressivamente a outros possujdores, e até mesmo no recinto desta Cidade não cessa semelhante translaçāo de domínio". ${ }^{46}$

Nos anos de 1857.58, os especuladores voltariam a ser responsabilizados, c não s6 por parte da Câmara Municipal, pelo agravamento da carestia. $\mathrm{Um}$ incidente comum foi relatado em fevereiro de 1857 pelo administrador de um posto municipal na entrada da cidade, segundo o qual uma boiada teria passado clandestinamente e os vaqueiros resistiram quando descobertos e intimados a retorná-la para o posto. O funcionário pediu reforço militar para agir no caso, mas sendo o gado de um senador duvidamos que o incidente tivesse tivesse resultado em punição. ${ }^{47}$ Num inquérito feito junto a várias auto-

46. AMS, Officios ao Governo. 1835-40, livro 111.9. As. $77.82 v$.

47. AMS, Oficios recebidos, 1857, nב̃o catalogado. ridades no início de 1858 , o presidente Sinimbu ouviu de um delegado de subúrbio de Salvador:

"a causa [da carestia] que existe, quanto do meu entender, $c$ pelo que se vê, é existirem pessoas, que tomando em atacado todos os gêneros proibem que sejam estes comprados pelos consumidores em primeira māo, vendo-se porén estes na necessidade de sujeitarem-se aos grandes preços por eles estipulados". 48

Como vimos, os especuladores seriam responsabilizados também pela Câmara nesse período. Num dos documentos da polêmica com o presidente, os vereadores informaram a Sinimbu:

"A farinha de mandioca (assim como a carne verde) acha-se entregue a três ou quatro indivíduos somente, os quais podem, sempre que querem, estabelecer a carestia simulando a falta desse gênero de primeira necessidade, tão indispensável é à alimentação pública, por isso que únicos a se ocuparem desse gênero de comércio, e dispondo dos capitais precisos para seu empreendimento, podem assenhorear-se de toda a farinha que chega a este porto, e depois dar-lhe os preços que thes convém e assim sustentarem a carestia e o monopólio, que mais se agrava com essa liberdade de vendagem, porque, aumentando-se consideravelmente o número dos revendões, mais fâcil se torna a sustentaçāo do preço que os primeiros agentes houverem estabelecido". ${ }^{49}$

Na opinião da Câmara o monopólio na venda a grosso definiria o patamar alto dos preços, mas a postura nāo contempla especulação que pudesse acontecer dentro mesmo do celeiro. Diante disso, quem estaria afinal sendo penalizado seriam os pequenos retalhistas. Eliminada essa intermediaçāo, o consumidor agora compraria diretamente dos monopolistas?

48. Francisco Gomes de Almada para o Presidente da Provincia, 2.01.1858, APEBa, Abastecimento, maço 4631 .

49. Câmara ao Presidente da Provincia, 17.02.1858, APEBa. Câmara de Salvador, maço 1404. 
Uma lógica estranha e que causou reação desde quando a postura fora estabelecida no inf́cio de 1857. Nessa ocasiāo seis pequenos comerciantes do Celeiro Público acusaram negociantes portugueses de açambarcadores de farinha:

"não podem [os queixosos] adquirir farinhas para a vendagem, por serem todas elas compradas por atacado por vários PorIugueses, que no mesmo Celeiro tem caixão com vúrios Africanos seus protegidos e escravos os quais apenas chegam os barcos compram por atacado o carregamento, e recolhido ao Celeiro poem-lhe o preço, e deste modo sempre se acham sortidos de farinha $[. .$.$] marcada pelo preço que thes parece". st$

Com dinheiro e africanos, os portugueses dominariam o celeiro "e por tal modo iludem a boa intenção, e medidas adotadas tão prudentemente por este mesmo Senado" da Câmara, concluiam os peticionários. Ao longo do texto cles demarcaram bem o campo da disputa entre "brasileiros natos", que estavam perdendo, e estrangeiros, que venciam.

Seja como for, pelo menos a curto prazo, a medida dera resultado imediato em 1858. Relembramos as contas feitas pelo cônsul inglês de que, de um dia para o outro, o preço da farinha cairia de 5 mil réis para $3 \$ 800$ o alqueire. Se a medida não eliminou a ação dos monopolistas, satisfez momentaneamente ao povo pobre.

Em todo lugar o que a população envolvida em food riots demandava era precisamente comida barata, ou melhor, "preço justo", accessívcl, a que populaçāo achava ter direito. Este, por seu turno, não era arbitrariamente estabelecido, mas resultava de uma experiência histórica que pode ser em parte também buscada no movimento de longo prazo dos preços. Como vimos há pouco, a longo prazo houve uma ten-

50. AMS, Requerimentos, 1857 , não catalogado. dência à estabilidade dos preços de farinha no século XIX. Em outras palavras, o consumidor se acostumara - e costume é central à economia moral - a ter acesso a este produto e daf seu descontentamento quando a escassez, agravada pela especulação, se estabelecia. O que espanta é que a Bahia não tivesse testemunhado mais movimentos como os de $1858 \mathrm{em}$ sua historia oitocentista, porque não foram poucos os anos de carestia. À exceção dos movimentos matamarotos logo após a Independência e em 1831, motins estes que associaram anti-lusitanismo a protesto contra a carestia, não aconteceram senão incidentes menores. $\mathrm{Na}$ verdade mais tensōes do que conflitos. Coisas assim: em 1837, às vésperas da rebeliāo da Sabinada, um juiz de paz da freguesia da Sé pediu reforço policial para evitar distúrbios por parte da "grande multidão de povo, que [...] concorre a comprar carne [...] visto a quantidade de carne que se expõe à venda nāo chegar para satisfazer ao mesmo povo"." Outro exemplo: em 1834, desta feita numa vila do Recôncavo, um outro juiz de paz seria obrigado pela multidāo a confiscar a farinha de um atravessador e a vendê-la a um preço razoável, um caso típico de taxation populaire, cena muito comum nos movimentos europeus. ${ }^{52}$

Do que se conhece até agora, o motim de 1858 foi o mais sério movimento especificamente contra a carestia desde o início do século XIX. E como vimos, ele começou quase por acaso na Santa Casa. $O$ cpisódio, no entanto, esteve impregnado de sentidos que vale a pena decompor.

51. Felix da Graça P. Lisboa para o Chefe de Polícia, 3.09.1837, APEBa, Correspondência da Secretaria de Policia, maço 3139.9.

52. APEBa, Tribunal da Relação, maço 2188. 
Há um conjunto de aspectos que, na mentalidade de recolhidas da Santa Casa e manifestantes da praça identificava as freiras francesas ao presidente da província. Tanto elas como ele eram de fora da província, e não estariam sintonizados com os interesses, as vontades, tradições, expectativas e em especial as relações sociais paternalistas da população local. As recolhidas escreveram um documento onde diziam: "tínhamos por nosso pai" ao provedor da Misericordia - e por isso haviam inicialmente aceito de bom grado as freiras por ele recomendadas. Mas tendo ele e outros membros da mesa tomado o partidos das francesas, as moças concluiram que "passaram de nossos pais a ser nossos padastros".53 Por outro lado, as petições ao presidente vistas acima também tinham um espírito de busca de proteção paternalista, com as pessoas expondo seus sofrimentos pessoais e familiarcs aos pés da autoridade. Freiras e presidente, elas através da disciplinarização rígida, ele pela rigidez de seu liberalismo econômico, não se acomodaram à ideologia paternalista baiana. Não souberam negociar, um aspecto importante dessa ideologia. Ganharam, ao contrário, a imagem de déspotas vindos de longe. Naquele domingo essa associação entre os dois poderes se fez na voz dos manifestantes, inclusive através da metáfora sexual, lembrando que se ouviram na praça gritos de que Sinimbu comia - já que cstamos tralando de comida - as freiras.

E tanto no recolhimento, quanto na praça a comida esteve no prato da rebeldia. As irmãs haviam diminuido e piorado a ração das recolhidas sob a alcgação de que elas a vendiam "por preços miseráveis

53. As Recolhidas da Casa da Santa Misericórdia ao Presidente da Províncis, 23.03.1858, APEBa, maço 5285. a sujeitos já com isso afreguezados", conforme denunciou o escrivão da Santa Casa em longo documento que escreveu e publicou como a versão oficial dos acontecimentos (BRUM, 1858, p. 13). Notem bem: mesmo se para benefício próprio, elas vendiam comida barata - a "preços miseráveis" - numa conjuntura de fome. Elas resolviam o problema de poucas pessoas, mas que certamente apreciavam o gesto. Um gesto que, para além daquelas pessoas, naquele momento de crise, tinha um enorme valor simbólico. As moças, que também tinham sua versão da administração das vicentinas, quase nada disseram sobre comida, mas o que disseram é esclarecedor: "obrigamnos a comer ao uso francês". ${ }^{4}$ Certamente não estavam se queixando de receitas de Babete. Significava comida pouca e exótica, para elas ruim, do tipo carne com osso e farinha com caroço. Supomos que, além de comerem mal, deixaram de ter o excedente que vendiam através das grades do recolhimento. Eis uma relação direta entre o que se passara na Santa Casa e na praça naqueles dias.

Outro detalhe compõe o cardảpio do conflito disciplinar no interior do recolhimento. $O$ escrivāo da Misericórdia sugeriu que, entre os "abusos" pepetrados pelas moças e que as irmãs tentaram "extirpar", cstavam "a depravaçāo dos seus devotos, e os interesses mesquinhos dos fregueses de rações" (BRUM, 1858, p. 17). Em lugar de "devotos", leiase amantes, namorados. $\mathrm{E}$ assim o escrivão também fez uma associação implícita entre sexo e comida. Afetividade e comensalidade se complementavam. Nós supomos que devotos $\mathrm{c}$ fregueses - homens $\mathrm{em}$

54. As Recolhidas da Casa da Santa Misericórdia ao Presidente da Província, 23.03.1858, APEBa, Correspondência, maço 5285 . 
alguns casos talvez desempenhando ambos os papéis - estiveram na Misericórdia ao lado delas e na praça agitando Salvador contra a carestia.

Mas em 1858 a luta em torno de comida esteve vinculada à luta por um conjunto de dircitos adquiridos. Houve uma importante dimensão política, entendida esta como rebeldia contra poderes instituídos e identificados como "despóticos". Vista por este ângulo, amplia-se a percepção da confluência de interesses entre as amotinadas da Santa Casa e os da praça. O documento escrito pelas mulheres é uma expressāo clara e rara da rebeldia feminina coletiva naqueles dias, e que as situa como cúmplices dos homens que brigaram na praça, não como coitadinhas por eles protegidas. Ali queixaram-se de que as irmãs haviam desmontado seus "cubículos" para alojá-las promiscuamente num grande sajāo: queriam "que dormissemos e lavássemos como pretas da Costa em bandos"; interditaram visitas de parentes e "chegar às janelas para esparecerem, apesar das grades"; suspenderam festa no Natal e proibiram que beijassem as imagens de seus santos de devoção. Segundo clas, as irmãs as puniam fisicamente e tcriam inclusive mandado fazer um tronco para ali castigá-las, outra alusāo ao tratamento escravocrata que recebiam. No mesmo sentido, o escrivão teria tratado "a uma de negra por ser de cor escura". Por outro lado, as irmãs haviam transferido o confessionário para um quarto isolado, onde temiam clas que fossem assediadas sexualmente pelo novo padre lazarista confessor. Em suma, e entre outras coisas, elas defenderam sua privacidade, direito de se comunicar com o mundo das ruas, de exercer suas formas tradicionais, brasileiras de devoção; denunciaram maus-tratos físicos, humilhaçōes, racismo $\mathrm{e}$ perigo sexual. Ao longo do texto, chamaram a superiora de "víbora" e "intrusa", este último epíteto sig. nificativo à vista de várias passagens em que o estrangeirismo das irmãs aparece como responsável por suas atitudes. ${ }^{55}$
Menos sistemáticos na revelação de suas idéias, ao contrário das recolhidas, as palavras dos amotinados da Praça não foram postas no papel; suas denúncias e reivindicaçōes foram faladas, na verdade gritadas na rua. Mas suas demandas não deixaram de ser sistematizadas através da palavra escrita, pois as tiveram representadas pela Câmara de Salvador. Os manifestantes brigaram pela postura da Câmara no dia um do conflito, e contra a demissão dos vereadores que a escreveram no dia dois.

A luta contra a carestia e em defesa da representação política considerada legítima cstiveram imbricadas. Ao contrário da presidência, ocupada por nomeação imperial, o cargo de vereador era eletivo $\mathrm{e}$ apesar de muitas restriçōes ao voto - mulheres não votavam, por exemplo - os nove vereadores de 1858

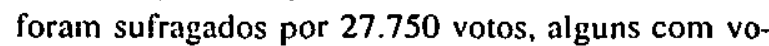
tação suficiente para se eleger hoje $\mathrm{cm}$ Salvador. $O$ mais votado e presidente da câmara recebera 4.301 votos. Eram homens com raízes locais $\mathrm{c}$ populares, seis deles simultâneamente vereadores $\mathrm{c}$ juízes de paz, cargo também eletivo responsável pelo policiamento das freguesias. ${ }^{56}$ A Câmara tinha cntĩo motivo para afirmar orgulhosamente, naquele ofício a Sinimbu, que era "representante do povo deste município". Do povo livre, Icmbramos. Quando invadiram a Câmara e protestaram "como cidadãos" contra a cassação de seus cleitos, os amotinados buscavam a restituição de direitos políticos sonegados pelo presidente. Essa passagem do motim confirma que os amotinados não

55. Este documento e o de Canto Brum são também discutidos por Nascimento (1992).

56. Sobre as regras para eleiçōes municipais, ver lei dos municípios de 1828 in Colleçăo (1886, vol. 2, pp. 310-4). O resultado das eleiçōes de 1856 está ernAPEBa, Câmara, maço 1403. Sobre vercadores juízes de paz consultar Masson (1858). 
foram apenas os absolutamente miseráveis. Como sugere Thompson (1991, p. 265), um movimento deste tipo não é feito por gente completamente destituída e desesperada, mas por péssoas que "sentem que têm um pouco de poder para ajudar a si próprios". Ele escreveu isso no sentido estrito da economia moral. $\mathrm{Na}$ Bahia de 1858, a luta contra a carestia, insistimos, se mesclou com a luta mais ampla em torno de direitos políticos adquiridos, ganhando uma linguagem de defesa da cidadania. Isso emprestou maior densidade política à economia moral. ${ }^{57}$

Entender este motim apenas nos termos de uma disputa entre a política econômica paternalista (economia moral) da Câmara municipal, de um lado, e a política econômica liberal (economia política) do governo provincial, do outro, seria uma visão tão pobre quanto atribuir o movimento à oscilaçāo de preços. Ver desta forma o conflito de 1858 seria vêlo somente de cima para baixo. Como escrevera o vereador Manoel Ferreira, os manifestantes nāo se opuseram a uma abstrata doutrina do livre mercado, mas contra um poder provincial que, ao contrário do poder municipal, não estava respondendo a suas demandas por comida barata. É claro que aquele povo apostava na proteção da Câmara, mas ele acreditava que também precisava proteger a Câmara. Essa relação de reciprocidade refletia um processo complexo de construção da cidadania no âmbito da cidade, no sentido de construção política dos interesses dos seus habitantes (livres) através de instituições legítimas. Nisso - e no direito a comida barata - residiam a legitimidade do movimento. Desse processo fazia parte, em 1858, a restituição da ordem subvertida por Sinimbu. A ordem para os ma-

57. A dimensão politica dos food riots e enfatizada por Tilly (1971). nifestantes residia na postura dos vereadores e na liberdade destes de exercerem seu papel de reguladores do mercado. Foi neste sentido um motim restauracionista (como foi restauracionista a rebeldia das recolhidas em busca de uma ordem anterior àquela instalada pelas freiras francesas).

Se pensarmos no movimento fora do momento de eclosão, sua densidade política aumenta. Levese em conta, por exemplo, que durante as semanas que $o$ antecederam foram desenvolvidas atividades subterrâneas - e noturnas - indicativas de alguma organização prévia. Neste caso se incluem os pasquins que apareceram afixados à noite nas ruas de Salvador ameaçando de morte o presidente. De forma menos direta, podemos incluir a crescente manifestação de grupos organizados de trabalhadores através das petições ao presidente e outras autoridades. Embora perfeitamente integradas ao mecanismo institucional vigente, elas revelam um grau de elaboração coletiva da crise que, imaginamos, desembocou na praça do palácio nos dias do motim.

Quanto ao que aconteceu nas ruas nesses dias, cabe ressaltar a revelação de lideranças populares que certamente não se fazem de uma hora para outra. Lembramos da ação do guarda nacional Santana, incitando o povo contra as irmās, ou do carpinteiro Justiniano, cuja fanfarronice o fez suspeito de desempenhar um papel maior no motim. Some-se a isso um repertório de açōes coletivas historicamente consagradas e que, mais uma vez, diziam respeito à relaçāo entre a Câmara e a cidade. ${ }^{58}$ Nas revoltas que pontilharam a Bahia na primeira metade do século XIX, a primeira ação dos rebcldes era ocupar a Câmara e convocar o povo, em geral com o loque do sino, tal como ocor-

58. Sobre tais "repentórios", num outro contexto, ver Bohstedt (1992, pp. 270-271). 
reu em 1858. O ato de tocar o sino emprestava uma dimensão ritual aos movimentos, um ritual político que solenizava a sua legitimidade ao chamar os habitantes da cidade a abraçá-los e ampliá-los. Nessas horas, a casa da Câmara constituia referência simbólica de um imaginado poder popular. O que aconteceu em 1858 na verdade reeditava, com as devidas inovaçōes, uma tradição da Bahia rebelde.

Isso significa, insistimos, que nāo basta levar em conta apenas a barriga do povo $e$ a cabeça do poder para explicar o motim da "carne sem osso e farinha sem caroço". Uma rede complexa de comportamen. tos, necessidades, interesses e desejos (não esquecendo das recolhidas e seus "devotos") balançou Salvador durante aqueles dois dias. E uma combinação de fatos. É provável que o motim não tivesse ocorrido sem o incidente da Misericórdia e a disputa envolvendo a Câmara e o presidente. Em movimentos

\section{Bibliografia}

AGUIAR, Pinto de. Abastecimento: crises, motins e intervençäo. Rio de Janeiro, Philobiblion, 1985

AMARAL, Braz do. Recordações históricas. Porto, Typographia Econômica, 1921.

ANDRADE, Maria Jose de S.. "Os recolhimentos baianos - seu papel social nos séculos XVIII e XIX". Revista do Instituto Geográfico e Histórico da Bahia. 90 (1992), pp. 225-237.

ARAS, Lina Brandz̄o. "A Santa Federação Imperial. Bahia, 18311833". Doutorado. USP. 1995.

ARROM, Silvia e ORTOLL, Servando (orgs.). Riots in the Cities: Popular Politics and the Urban Poor in Latin America. Wilmington, DE, SR Books, 1996.

BARICKMAN, Bert. "The Slave Economy of Nineteenth-Century Bahia: Export Agriculture and Local Market in the Recôncavo". PhD, University of lllinois at UrbanaChampaign, 1991.

BÉLIVEAU, Dénis. "La paricipation des femmes aux révoltes frumentaires en France dans la premiére moitié du XIXe siècle". desse tipo a carestia é uma condiçāo necessária, mas não suficiente.

Talvez isto explique porque, no ano seguinte, quando o preço da farinha bateu o recorde da década, Salvador manteve-se em paz. Em junho de 1858. logo após a saída de Sinimbu da Bahia, o vice-presidente em exercício, Manoel Messias de Leão, aprovaria a postura da Câmara, e em outubro a Assembléia Provincial a ratificaria. Mas a carestia persistiu. Em novembro, o pedreiro Theodosio da Costa Lima, que se ocupava de obras públicas, já desistira de acreditar na capacidade das autoridades locais de resolverem seu problema e escreveu diretamente ao Imperador, esse protetor distante, pedindo aumento salarial. Sua remuneração, queixou-se, "na época actual, quando a carestia nos aperta em seos braços de ferro, não pode chegar para a alimentação de uma familia grandiosa". 59

59. Theodosio da Costa Lima para o Imperador, 1.11.1858, APEBa, Correspondência ao Imperador, maço 646.

In Révolte et Societé (actes du IVe Coloque d'Histoire au Présent) (Paris, Histoire au Present, 1988), vol. 11, pp. 140-148. BOHSTEDT, John. "Gender, Household and Community Politics: Women in English Riots 1790-1810".Past \& Present, 120 (19988), pp. 88-122.

"The Moral Economy and the Discipline of Historical Context". Journal of Social History, vol. 26, $\mathrm{n}^{\circ} 2$ (1992), pp. 265-264.

BRUM, Bernardo do Canto. Relatorio feito pelo Irmäo Escrivão da Santa Casa da Misericórdia desta cidade ao Irmão Posvedor o Exm ${ }^{\circ}$ Conselheiro Joäo Mauricio Wanderley a res. peito dos acontecimentos que no dia 28 de fevereiro deste anno tiveräo lugar no Recolhimento. Salvador, Typogmphia de Carnillo de Lellis Masson \& C., 1858.

CASTRO, Jcanne Berrance de. A milícia cidada: a Guarda Naci. onal de 1831 a 1850. São Paulo, Editora Nacional, 1979. "O negro na Guarda Nacional brasileira". Anais do Museu Paulisı, 23 (1969), pp. 149-172. 
COLLECÇAO das leis do Imperio do Brazill. Ouro Preto, Typ. Silva, 1886.

DAVID, Onildo Reis. $O$ inimigo invisivel: a epidemia do cólera na Bahia, 1855.56. Brasília, Sarah Letros, 1996.

FRAGA FILHO, Walter. Mendigos, moleques e vadios na Bahia do seculo XIX. Sro Paulo, Hucitec, 1996.

HOBSBAWM, E. J.. Primitive Rebels. Nova lorque, Norton, 1959. "Movimentos pre-politicos em áreas periféricas" (e comentários de Boris Fausto, Maria Isaura P. de Queirós, Octavio Velho e verena Stolcke). In PINHEIRO, Paulo Sérgio (org.), O Estado autoritário e movimentos sociais (Rio de Janeiro, Paz e Terra, 1979), pp. 239-304.

HOLTON, Robert. "The Crowd in History: Some Problems of Theory and Method". Social History, vol. 3, n 2 (1978).

KRAAY, Hendrik. "Soldiers, Officers, and Society: The Arıny in Bahia, Brazil, 1808-1889". PhD, The University of Texas at Austin, 1995.

LE BON, Gustave. The Crowd. Nova Iorque, The Viking Press, 1960.

MASSON, Camillo Lellis (org.). Almanak administrativo, mercantil e industrial. Salvador, Typ. de Camillo Lellis Masson, 1858.

MATTOSO, Katia. Bahia: a cidade do Salvador e seu mercado no século XIX. Sāo Paulo, Hucitec, 1978.

Bahia, século XIX: uma província no lmpério. Rio de Janeiro, Nova Fronteira, 1992.

MAURAN, Corine. "Le rôle des femmes dans les émotions populaires dans les campagnes de la generalité de Lyon de 1665 a 1789". In Révolte et Societé (actes du IVe Coloque d'Mistoire au Présent) (Paris, Histoire au Présent, 1988), vol. II. pp. 134.139.

MORTON, F. W. O. . "The Conservative Revolution of Independence: Economy, Society, and Politics in Bahia, 1790-1840". PhD, Oxford University, 1974.

NASCIMENTO, Ana Amélia V.. Dez freguesias da cidade de Salvador. Salvador, Fundaçăo Cultural do Estado, 1986.

"A pobreza e a honra: recolhidas e dotadas na Santa Casa de Misericórdia da Bahia, 1700-1867". Revista da Academia de Letras da Bahia, 38 (1992), pp. 123-134.

PERROT, Michelle. Os excluidos da história: operirios, mulheres, prisioneims. São Paulo, Paz e Terra, 1988.
REIS, Jol̄o José. "A elite baiana face aos movimentos sociais: Bahia, 1824-1840". Revista de História, 108 (1976), pp. 341-384.

Rebeliäo escrava no Brasil: a história do levante dos malês (1835). Săo Paulo, Brasiliense, 1986.

A morie é uma festa: ritos fünebres e revolta popular no Brasil do século XIX. Sĩo Paulo, Companhia das Letras. 1991.

"A greve negra de 1857 na Bahia", Revista USP, 18 (1993), pp. 6-29.

RIDINGS JR., Eugene. "The Bahian Commercial Association, 1840-1889". PhD., The University of Florida, 1970.

RUDE, George. The Crowd in History: A Study of Popular Disturbances in France and England, 1730-1848. Nova lorque, John Wiley \& Sons, 1964.

RUY, Affonso. Historia da Camara Municipal da Cidade do Salvador, 2a ed.. Salvador, Câmara Municipal de Salvador, 1996.

SOARES, Cecília Moreira. "A mulher negra na Bahia no século XIX". Mestrado, UFBa, 1994.

SOUZA, Paulo César. A Sabinada: a revolta separatista da Bahia (/837). São Paulo, Brasiliense, 1987

STEVENSON, John. Popular Disturbances in England. 1700. 1870. Londres e Nova Iorque, Longman, 1979.

THOMPSON, E. P.. "The Moral Economy of the English Crowd in the Eighteenth Century". Past \& Present, 38 (1971), pp, 76-136.

. Customs in Common: Studies in Traditional Popular History. Nova Iorque, The New Press, 199I.

TILLY, Louise. "The Food Riot as a Form of Political Conflict in France". Jaurral of Interdisciplinary Histary, vol, $2, n^{\circ} 2$ (1971), pp. 23-57.

TILLY, Charles e TILLY, Richard. The Rebellious Century: 1830-1930. Cambridge, Harvard University Press, 1975.

WILDBERGER, Arnold. Os presidentes da província da Bahia. Salvador, Typographia Beneditina, 1949.

WILLIAMS, Dale E.. “Were 'Hunger' Rioters Really Hungry? Some Demographic Evidence". Past \& Present, 71 (1976), pp. 70-75.

. "Morals, Market and the English Crowd in 1766". Past \& Present, 104 (1984), pp. 56-73. 